\title{
Phosphorus removal from Nigeria's Agbaja iron ore by solubilization with Eurotium herbariorum
}

\author{
O. W. Obot ${ }^{1 \star}$ and C. N. Anyakwo ${ }^{2}$ \\ ${ }^{1}$ Department of Mechanical Engineering, Faculty of Engineering, University of Uyo, Nigeria. \\ ${ }^{2}$ Department of Metallurgical and Materials Engineering, Federal University of Technology, Owerri, Nigeria.
}

Accepted 1 August, 2011

\begin{abstract}
Phosphorus is an unwanted component of iron ore. Its removal from Nigeria's Agbaja iron ore by solubilization with Eurotium herbariorum isolated from the ore samples has been achieved using the submerged culture technique. Result obtained shows $61.48 \%$ removal of $P$ in 10 weeks through the biomass growth and activities of the filamentous fungus. The biomass dry weight of the fungus increased from an initial $1 \mathrm{~g}$ (dry weight of inoculums) to a maximum $3.021 \mathrm{~g}$ weight in 3 weeks only to drop to $0.486 \mathrm{~g}$ by the end of experiment. The ability of the fungus to metabolize the phosphorus in ore was noticed to increase with biomass weight but hindered over time. Extended duration of degradation after 7th week did not necessarily bring about more $\mathbf{P}$ removal. Phosphorus utilization by the fungus resulted in its growth and concomitant production of acidic metabolic products and adsorption of detectable concentrations of iron, copper, lead, zinc, cadmium and manganese from the ore samples. It is therefore suggestive that the fungus activity can enhance the purity of ores and if the metabolic wastes associated with the process are timely and well managed, it is possible degradation could be continuous in view of microbial exponential growth rate.
\end{abstract}

Key words: Phosphorus, removal, iron ore, Eurotium herbariorum, broth, inoculation.

\section{INTRODUCTION}

The high level of phosphorus in Nigeria's Agbaja iron ore is not beneficial according to Amadi et al. (1982) and Uwadiale and Nwoke (1983a). The negative effects of phosphorus in high quality steels namely: the effect of steel brittleness coupled with the effect of strong primary segregation during solidification of castings and the formation of high phosphorus brittle streaks between metal grains which impede plastic deformation are undesirable and therefore should be minimized as much as possible. A desirable range of 0.020 to $0.030 \mathrm{Wt}$. \% has been reported by Kudrin (1985). Phosphorus elimination from ore has bothered many researchers from the early 80 s till now. Mainly the researchers sought ways of beneficiation of the ore and by end of the $80 \mathrm{~s}$ it had become clear that conventional methods were not solving the long standing problem associated with the ore

*Corresponding author. E-mail: obotowo2004@yahoo.com.
(Uwadiale and Nwoke, 1983a, b; Uwadiale and Okafor, 1983; Uwadiale and Whewell, 1988). In the recent past, attention of researchers has been turned to finding an alternative route to solving the high-phosphorus status of Agbaja iron ore by attempting the bio-beneficiation approach (Anyakwo and Obot, 2008, 2010) because of the advantages of ecologically and environmentally friendlier components offered by this method.

This research was conducted to investigate the possible elimination of phosphorus from Nigeria's Agbaja iron ore by Eurotium herbariorum with emphasis on titrimetrical analysis of sub-merged-cultured ore samples. It also involved system's $\mathrm{pH}$, trace metals accumulation and growth (biomass weight) monitoring.

\section{MATERIALS AND METHODS}

Source of ore samples

The iron ore was obtained from Agbaja near Lokoja, Kogi State of 


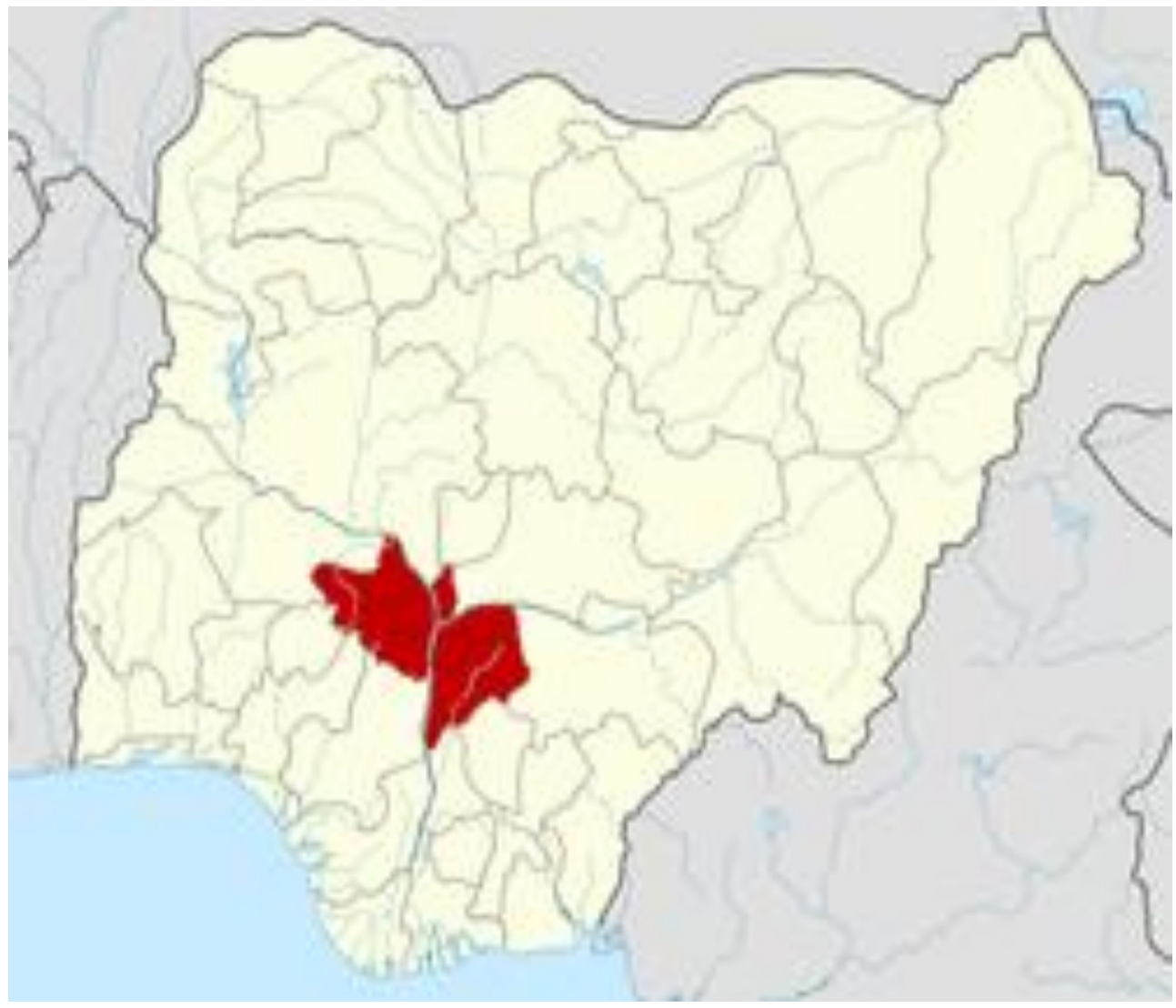

Figure 1. Map of Nigeria showing the iron ore rich Kogi State.

Nigeria (Figure 1). Agbaja iron ore reserve is estimated at over 1.2 billion tones (Uwadiale, 1991).

\section{Determination of compositional elements in Agbaja ore}

Prior to compositional analysis, some quantity of the ore was crushed and sieved using Shital test kits to obtain 0.50/0.25 mm particle size (Plate 1). Known quantities of the crushed ore samples were subjected to elemental analysis using standard procedures. The concentrations of the components in the samples were determined by indicated methods: Fe- AAS (UniCam 939), $\mathrm{SiO}_{2-}$ Colorimetry (using ammonium molybdate), $\mathrm{P}_{2} \mathrm{O}_{5}$ - Colorimetry (using ammonium vanadate), $\mathrm{MgO}, \mathrm{Cu}_{2} \mathrm{O}, \mathrm{ZnO}, \mathrm{MnO}_{2}-\mathrm{AAS}$ (UniCam 939), $\mathrm{S}$ - by Eschka method and $\mathrm{Al}_{2} \mathrm{O}_{3}$ by Titrimetry.

\section{Isolation and determination of solubilizing potentials of microorganisms associated with Agbaja ore}

Microorganisms on ore surface were cultured by spread plate technique on suitable media. Bacteria associated with the ore were isolated with Bacto- nutrient agar (NA), while the fungi were obtained with the aid of Sabouraud dextrose agar (SDA). The plates were incubated appropriately at room temperature $\left(28 \pm 2^{\circ} \mathrm{C}\right)$. Specific colonies were then sub-cultured on freshly prepared basal media and the pure cultures were characterized according to recommended procedures (Sneath and Holt, 1986; Alsina and Blanch, 1994; Barnett and Hunter, 1987). The ability of the microbial isolates to utilize the ore as their sole source of energy for growth was determined by the method of Okpokwasili and Okorie (1988) and Itah and Essien (2005) using the mineral salt medium (MSM) of Zajic and Supplison (1972). Briefly, $10 \mathrm{ml}$ of MSM were dispensed into each test tube and then $2 \%(0.2 \mathrm{~g})$ of the milled ore sample was added. The ore-supplemented medium was then sterilized by autoclaving at $121^{\circ} \mathrm{C}$ for 15 min under 15 psi atmospheric pressure. Thereafter $1 \mathrm{ml}$ of $18 \mathrm{~h}$ old tryptone soya broth culture of the bacteria isolates, and $1 \mathrm{~g}$ wet weight of fungi were aseptically seeded into the ore-supplemented MSM and then incubated un-disturbed at $28 \pm 2^{\circ} \mathrm{C}$ for three weeks.

Un-inoculated tubes were included for each test isolate to serve as controls. The surface mycelia spread of the fungi was used as the index of ability to utilize the ore medium for growth. The growth rate of the isolates was graded as high $(+++)$, moderate $(++)$, minimal $(+)$ and no growth (-). Among the isolates with strong capability to utilize ore based substrate for growth, E. herbarorium was the most prevalent and was subsequently selected for the $P$ removal studies.

\section{Determination of phosporus solubilzing capability of Eurotium herbarorium}

The submerged culture technique was adopted. In this procedure, $100 \mathrm{ml}$ of malt extract broth (MEB) was dispensed into $250 \mathrm{ml}$ conical flasks and thereafter supplemented with sieved ore. The ore supplemented MEB was sterilized as before and allowed to cool after which $1 \mathrm{~g}$ wet weight of the solubilizing agent (E. herbarorium) 
Table 1. Composition (\%) of Nigeria's Agbaja iron ore.

\begin{tabular}{lccccccccc}
\hline Component & $\mathrm{FeT}$ & $\mathrm{SiO}_{2}$ & $\mathrm{P}_{2} \mathrm{O}_{5}$ & $\mathbf{M g O}$ & $\mathrm{Cu}_{2} \mathrm{O}$ & $\mathrm{ZnO}$ & $\mathbf{S}$ & $\mathrm{MnO}_{2}$ & $\mathbf{A l}_{2} \mathrm{O}_{3}$ \\
\hline$\%$ content & 51.50 & 0.57 & 1.25 & 0.08 & 0.005 & 0.091 & 3.25 & 0.001 & 34.77 \\
\hline
\end{tabular}

Table 2. Ore solubilizing potentials of the microbial isolates.

\begin{tabular}{lcc}
\hline Microbial isolate (Fungi) & Prevalence (\%) in ore samples $(\mathbf{n}=\mathbf{7})$ & Growth on ore + MSM \\
\hline Aspergillus terreus & 50 & ++ \\
Aspergillus niger & 60 & ++ \\
Aspergillus parasiticus & 50 & +++ \\
Eurotium herbarorium & 70 & +++ \\
Fusarium sp & 40 & - \\
Mucor $s p$ & 50 & - \\
Penicillium citrinum & 60 & +++ \\
\hline
\end{tabular}

was seeded into each flask. Un-inoculated flask (Ore + MEB) served as control. They were left to stand for 10 weeks. During incubation, representative samples were removed at weekly basis for determination of phosphorus, $\mathrm{pH}$ and biomass weight of the solubilizing agent. The amount of $\mathrm{P}$ in ore-MEB was determined by standard volumetric analytical technique (Jain, 1982) in which ammonium phospho-molybdate precipitate was obtained and $P$ concentration in it analyzed by titrating the precipitate with $0.1 \mathrm{~N}$ $\mathrm{HCl}$ using 4 to 5 drops of phenolphthalein as indicator. The $\mathrm{pH}$ of the fermentation broth was determined using a pH meter (EIL 7020, Kent Industrial measurement Ltd). To determine the biomass weight of the solubilizing agent, the mycelium of the cultures were harvested by filtration, washed with several changes of cold distilled water, dried to a constant weight in a draft oven at $60^{\circ} \mathrm{C}$ and then weighed in a chemical balance. Also determined before and at the end of $P$ removal experiment were the trace metals levels in the ore-supplemented medium (ore + MEB) and in ore + MEB inoculated with $E$. herbarorium.

The concentrations of iron ( $\mathrm{Fe})$, copper $(\mathrm{Cu})$, cadmium $(\mathrm{Cd})$, zinc $(\mathrm{Zn})$, nickel $(\mathrm{Ni})$, manganese $(\mathrm{Mn})$ and lead $(\mathrm{Pb})$ in the substrates were determined with AAS after digestion with a solution of concentrated $\mathrm{HNO}_{3}(0.3 \mathrm{ml})$ and $\mathrm{HCl}(6.0 \mathrm{ml})$ (Binning and Baird, 2001).

\section{RESULTS AND DISCUSSION}

The results of ore compositional analysis data are presented in Table 1. Loss on ignition was taken at $939^{\circ} \mathrm{C}$. The results show rich $\mathrm{Fe}$ in the ore and as well confirm the high-phosphorus and high-alumina status of the ore which had earlier been reported by Uwadiale (1989). The Agbaja iron ore samples also habour diverse species of fungi with variable capabilities to utilize the components of the ore for growth (Table 2). Among the isolates with strong solubilizing potentianls was the most prevalent with $70 \%$ incidence rate in 7 samples of Agbaja iron ore samples analyzed. Pure cultures of the solubilizing agent $E$. herbarorium were used for the removal of $P$ in ore supplemented MEB over a period of 10 weeks. The observable changes in the system after it was inoculated with the solubilizing agent are illustrated in Figures 2 to 7 . Figure 2 presents the Wt. \% P content in the ore sample for 10 weeks solubilization by $E$. herbarorium. During this period, the Wt. \% P content in the ore reduced from 0.880 to 0.339 . However the $P$ solubilization process was not progressive towards the end; it rather slowed down resulting in a near stagnation. It is possible the fungs had entered the death stage after 6 to 7 weeks of active growth and concomitant production of metabolic products some of which may be toxic and probably hindered continuous growth. Figure 3 presents the curve of \% P uptake in 10 weeks by $E$. herbarorium. The curve shows that solubilization process was smooth but proceeded slowly towards the end from around Week 7. The decreasing solubilization rate over time can occur as a result of reduced nutrient supply or as a consequence of death or chelation of hyphae in the culture due to increasing concentration of harmful metabolites released into the substrate. Formation of toxic ore complexes such as pyrite in presence of oxygen and water has also been reported. Figure 4 presents the growth profile (biomass weight) of $E$. herbarorium cultured for 10 weeks in the ore supplemented medium. Starting from week 1 with $1.000 \mathrm{~g}$ dry weight the biomass weight of the fungus rose to $3.021 \mathrm{~g}$ dry weight by the 3rd week which later decreased to $0.486 \mathrm{~g}$ dry weight by the 10th week. The last 3 weeks did not show much growth. The earlier low solubilization observed is traceable to reduced biomass weight. The $\mathrm{pH}$ of the fermentation broth was affected by the solubilization process.

The utilization of ore by the fungus resulted in growth and concomitant production of acidic metabolites. It is observed from the curve (Figure 5) that with an initial $\mathrm{pH}$ 


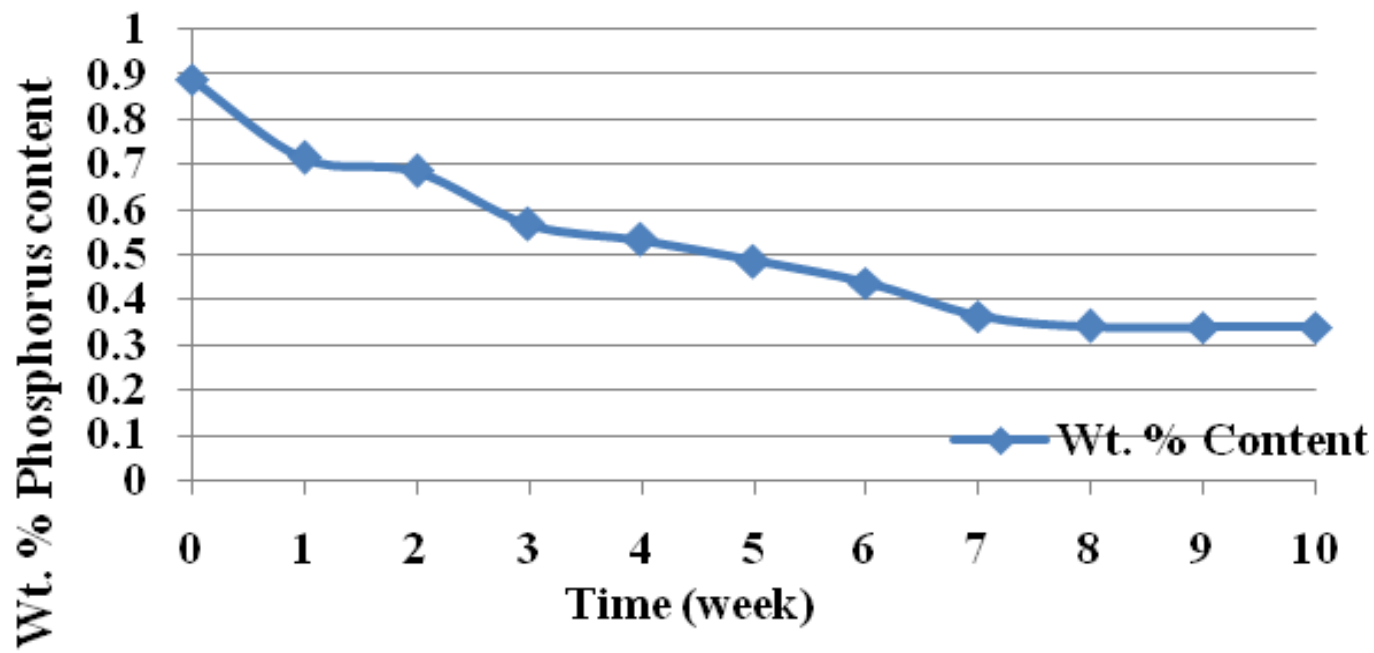

Figure 2. Changes in $\mathrm{P}$ content of fermentation broth during solubilization by Eurotium herbarorium.

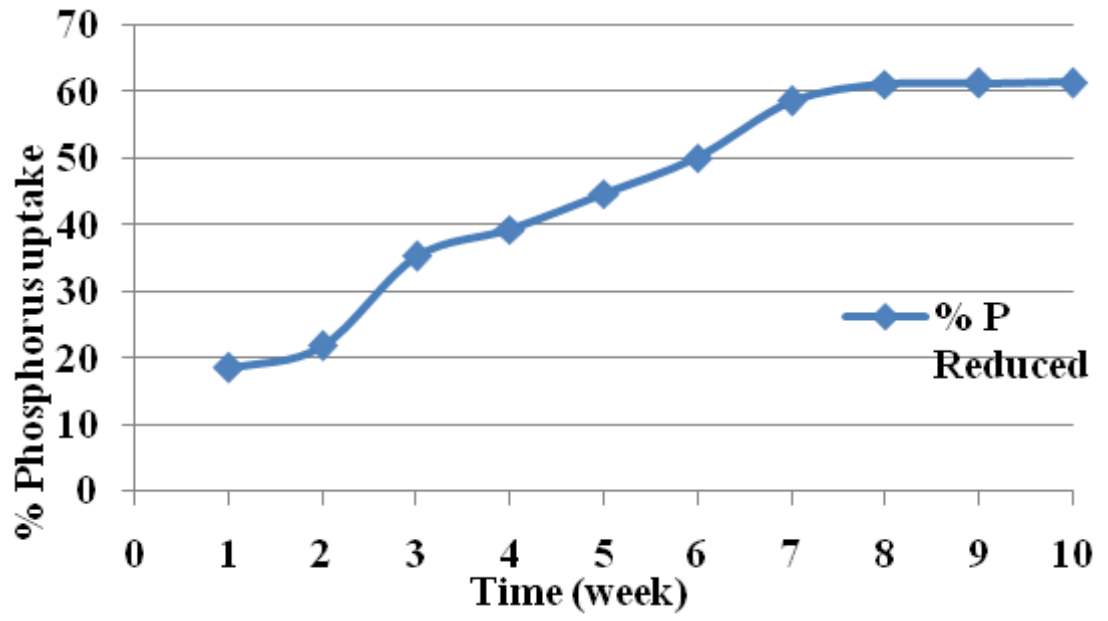

Figure 3. Solubilization curve of phosphorus uptake by Eurotium herbarorium.

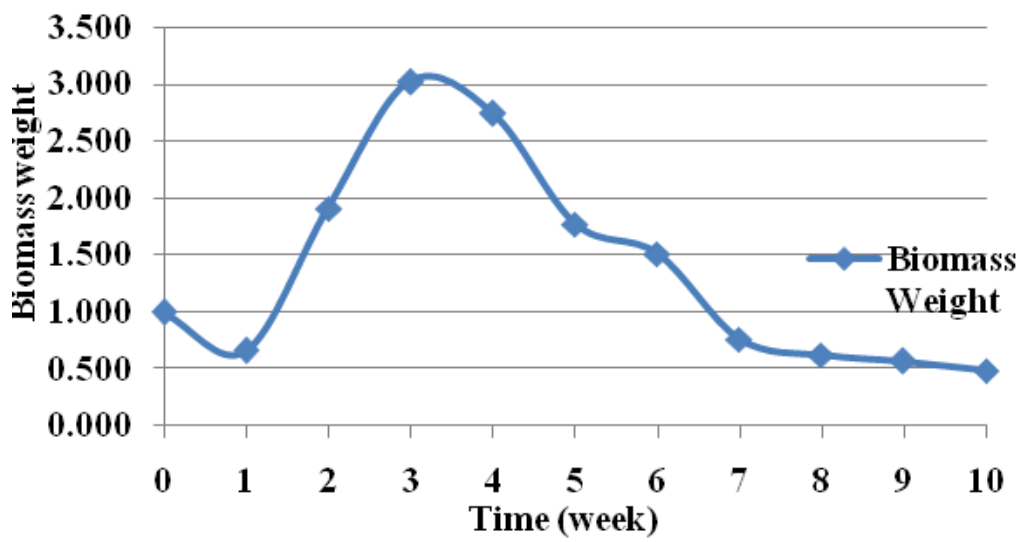

Figure 4. Changes in biomass weight during $P$ solubilization from oresupplemented MEB. 


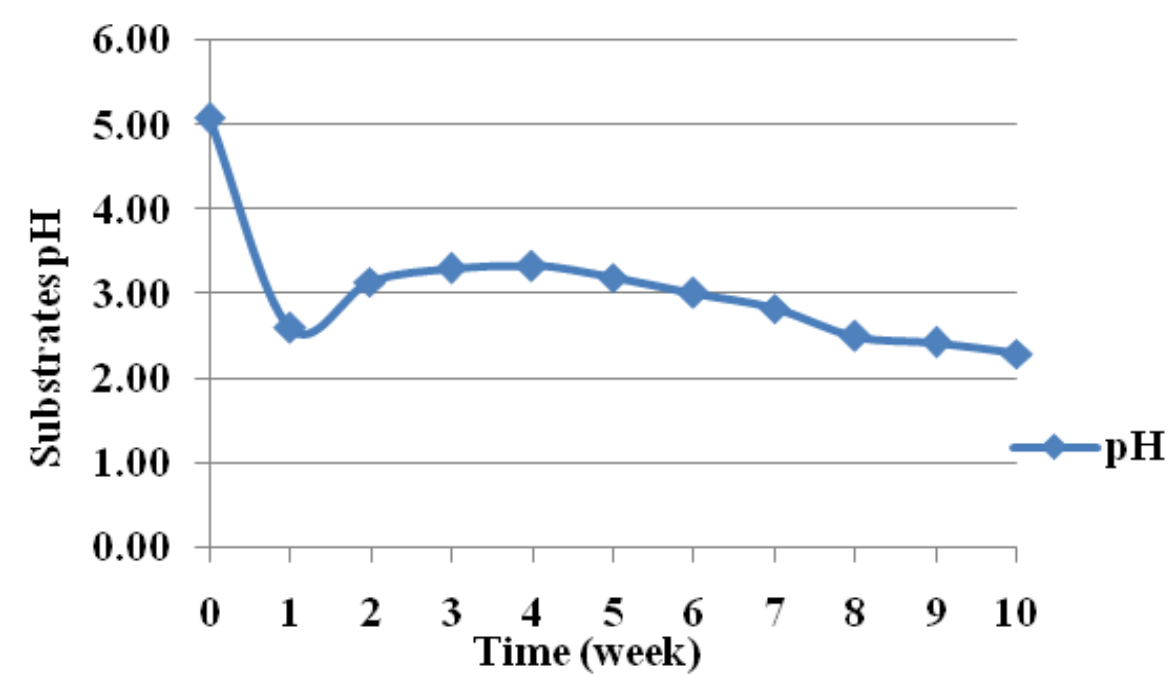

Figure 5. Changes in $\mathrm{pH}$ of fermentation broth during the solubilization of phosphorus in ore substrate by Eurotium herbarorium.
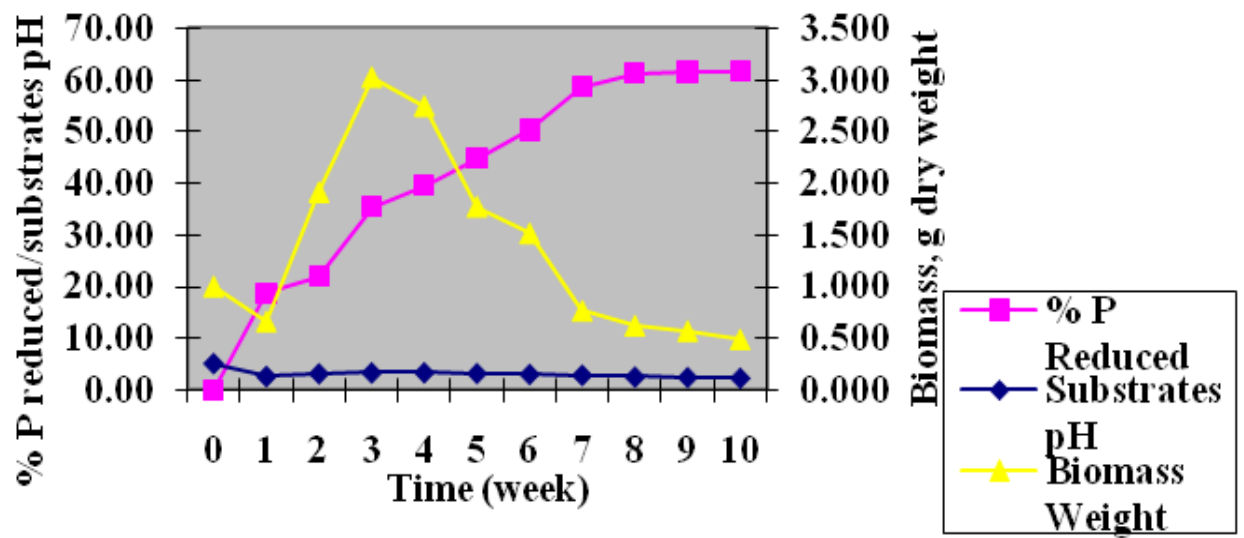

Figure 6. Activities trend of Eurotium herbarorium during the solubilization of phosphorus from ore $0.50 / 0.25 \mathrm{~mm}$ for 10

5.09 , the degrading process by the end of week 1 recorded an unusually increased acidity level of 2.61 . This however adjusted to 3.15 by the end of week 5 and thereafter increased progressively to 2.30 by week 10 . The acid levels in which $E$. herbarorium metabolized the ore samples can be considered normal because the fungus is acidophilic and could thrive in acidic conditions. The variation of WT. \% P content, substrates $\mathrm{pH}$ and biomass weight of $E$. herbarorium during phosphorus reduction of ore for 10 weeks is presented in Figure 6. This figure shows that in week 1 a rapid drop in biomass weight that also corresponded to a rapid drop in ore's phosphorus concentration occurred. Also, it shows that a marked increase in biomass weight occurred between weeks 1 and 3 while phosphorus intake by the microorganism was equally experienced. Post week 3 saw a gradual decrease of the biomass weight though phosphorus accumulation also continued. Phosphorus reduction by week 7 began to show signs of stagnation which also coincided with very low biomass weight of the fungus in highly acidic medium. The $\mathrm{pH}$ of the submerged cultures remained permanently in acidic region throughout the experimental duration. Elemental analysis of the test medium (MEB) showed that the addition of sieved ore increased the trace metals load of test medium. Figure 7 shows that the MEB culture is rich in Fe $17.0138 \mathrm{ppm}$ with rather very low concentrations of Cu 0.1399 ppm, Cd 0.0613 ppm and Mn 0.3335 ppm. It does not contain $\mathrm{Zn}, \mathrm{Ni}$ and $\mathrm{Pb}$. However, on supplementation (Figure 8), the concentrations of all the 


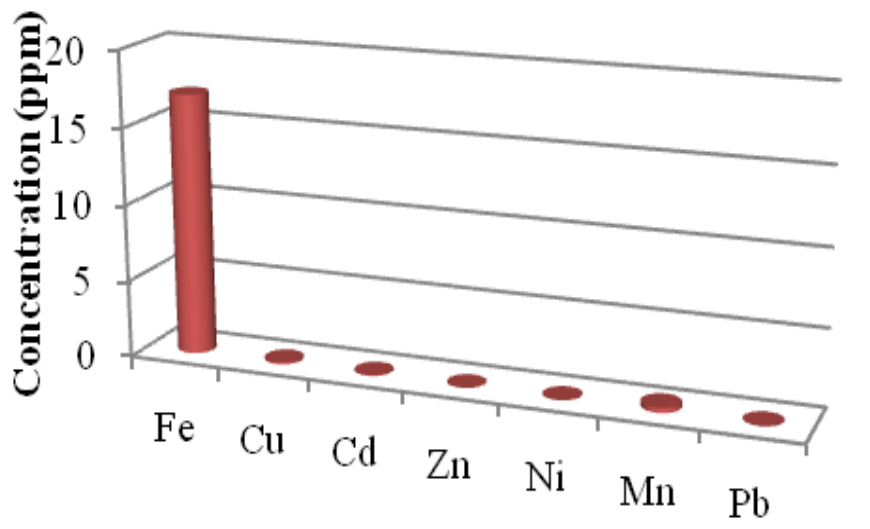

- MEB-pure

Trace Metal

Figure 7. Trace metals level in test medium (MEB) before supplementation with ore.

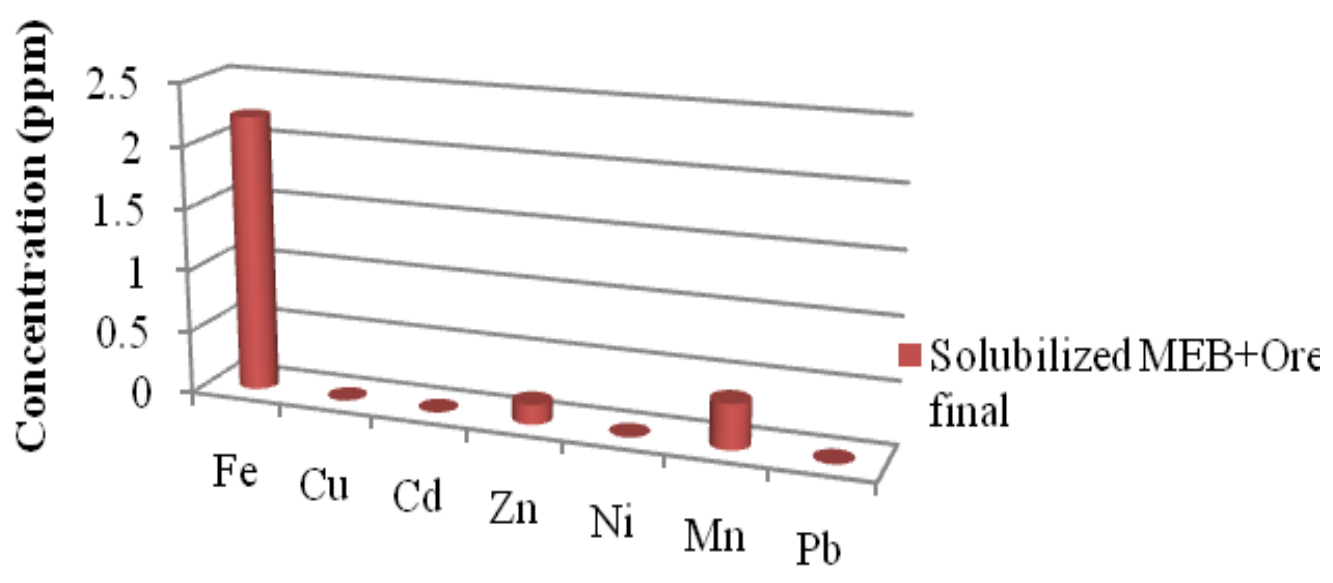

Trace metal

Figure 8. Trace metals level in test medium (MEB) after supplementation with ore.

metals but $\mathrm{Fe}$ and $\mathrm{Cd}$ increased. The reduction in $\mathrm{Fe}$ in MEB on addition of ore was not expected, but could be ascribed to formation of undetectable complexes. On the other hand, reasonable concentration of $\mathrm{Zn}$ and $\mathrm{Pb}$ (from 0 to 0.3080 and $1.0549 \mathrm{ppm}$, respectively) hitherto not detected in MEB was introduced by the ore. However, through the process of solubilization, the agent $E$. herbarorium in addition to removing $\mathrm{P}$ also adsorbed reasonable quantities of the trace metals leaving lower concentrations of the metals in the test medium (Figure 9). The uptake was remarkable and metals such $\mathrm{Cu}, \mathrm{Cd}$ and $\mathrm{Pb}$ was out rightly removed from the ore-MEB substrate. The research findings show that the fungus can bio-accumulate metallic ions under favorable conditions.

Monitoring of the fluctuation of heavy metals concentration in the MEB medium initially and at the end of 10 weeks showed that the solubilizing agent $E$. herbarorium accumulated 6 out of 7 trace metals detected in the ore. $\mathrm{Ni}$ was not present in the medium and may not have been present in Agbaja iron ore. Concentrations of $\mathrm{Cu}, \mathrm{Cd}$ and $\mathrm{Pb}$ ions were completely solubilized because their initial concentrations disappeared at the end of 10 weeks. The concentrations left in the media at the end of 10 weeks after the fungus had accumulated as much of the trace metals as they could were Fe $2.2187 \mathrm{ppm}, \mathrm{Zn} 0.1568 \mathrm{ppm}$ and $\mathrm{Mn}$ $0.33620 \mathrm{ppm}$. 


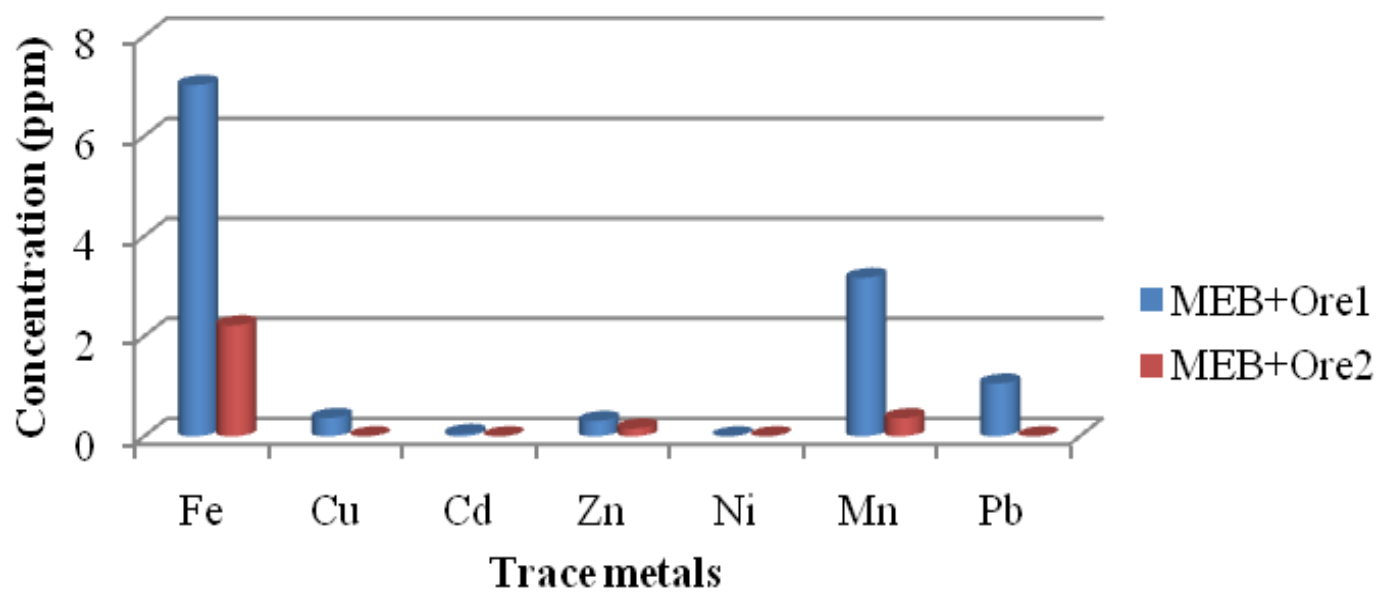

Figure 9. Effect of phosphorus solubilization by Eurotium herbarorium on trace metal levels of the ore supplemented malt extract broth (MEB) before (MEB + Ore 1) and after (MEB + Ore 2) incubation for 10 weeks.

\section{CONCLUSION AND RECOMMENDATION}

The possibility of eliminating phosphorus from Nigeria's Agbaja iron ore samples using a biological agent $E$. herbarorium in the course of 10 weeks was investigated and there were outstanding, analyzable effects. $61.48 \%$ of $P$ was solubilized by the filamentous fungus. The metabolic activity of the fungus in the fermentation broth was remarkable but later was reduced plausibly as a result of over-accumulation of toxic metabolites and/or exhaustion of available nutrients. These may result in cells (hyphae) lysis and death. Phosphorus utilization by the fungus resulted in its growth and concomitant production of acidic metabolic products and adsorption of detectable concentrations of iron, copper, lead, zinc, cadmium and manganese from the ore samples. It is therefore suggestive that the fungus activity can enhance the purity of ores and if the metabolic wastes associated with the process are timely and well managed, it is possible degradation could be continuous in view of microbial exponential growth rate.

\section{ACKNOWLEDGEMENTS}

We are grateful to all those who in one way or the other supported this research especially the staff at Microbiology and Chemical Engineering Laboratories of University of Uyo, Dr. Joseph Essien (Associate Professor of Microbiology), Mrs Christiana Udosen and Engr Peter Asangausung; the staff at Ministry of Science and Technology Laboratory, Akwa Ibom State. Also, we owe our gratitude to Dr. A. O. Ano and Mr. Nwosu of the Nigerian Root Crops Research Institute (NRCRI), Umudike, Abia State for lending scarce equipment without which the research would not have been done.

\section{REFERENCES}

Alsina M, Blanch AR (1994). A set of keys for biochemical identification of environmental Vibrios species. J. Appl. Bacteriol. 74:79-85.

Amadi NJ, Odunaike AA, Mathur JP (1982). Preliminary bench scale beneficiation studies with three lumps of iron ore sample from Agbaja. (Tech. Rep.). Central Metallurgical Research and Development Centre, Jos, Nigeria.

Anyakwo CN, Obot OW (2008). Phosphorus removal from Nigeria's Agbaja iron ore by Aspergillus niger. IREJEST., 5(1):54-58.

Anyakwo CN, Obot OW (2010). Phosphorus removal capability of Aspergillus terreus and Bacillus subtilis from Nigeria's Agbaja iron ore. JMMCE 9(12):1131-1138.

Barnett HL, Hunter BB (1987). Illustrated genera of imperfect fungi $\left(4^{\text {th }}\right.$ ed.), Macmillan Publishing coy, New York, Collier Macmillan Publishers, London.

Binning K, Baird D (2001). Survey of heavy metals in the sediments of the Swatkop River Estuary, Port Elizabeth South Africa. Water SA, 24(4):461-466.

Itah AY, Essien JP (2005), Growth profile and hydrocarbonoclastic potential of microorganisms isolated from tarballs in the Bight of Bonny, Nigeria, W. J. Microbiol. Biotechnol. 21:1317-1322.

Jain SK (1982). An introduction to metallurgical analysis: chemical and instrumental, India, New Delhi, Vikas Publishing House.

Kudrin V (1985). Steel making. Moscow: MIR Publishers.

Okpokwasili GC, Okorie BB (1988). Biodeterioration potentials of microorganisms isolated from car engine lubricating oil. Tribol. Int. 21:215-220.

Sneath HAP, Holt GJ (1986). Bergey's manual of systematic bacteriology, Vol. 2, Williams and Wilkins, Baltimore, London, p. 1599.

Uwadiale GGOO (1991). Electrolytic coagulation and selective flocculation of Agbaja iron ore. J. Ming Geol. 27(1):77-85.

Uwadiale GGOO, Nwoke MAU (1983a). Beneficiation of Agbaja iron ore by reduction roasting- magnetic separation: semi pilot plant scale-up and establishment of residence point of phosphorus, National Steel Council, Metallurgical Research and Tests Division, Jos, Nigeria.

Uwadiale GGOO, Nwoke MAU (1983b). Gravity concentration of Agbaja oolitic iron ore using a laboratory-size Wilfley shaking table. (Tech. 
Rep.). National Steel Council, Metallurgical Research and Tests Division, Jos, Nigeria.

Uwadiale GGOO, Okafor E (1983). Interim technical report of investigations: petrology of Agbaja ironstone. National Steel council, Metallurgical Research and Tests Division, Jos, Nigeria.
Uwadiale GGOO, Whewell RJ (1988). Effect of temperature on magnetizing reduction of Agbaja iron ore. Met. Trans. 19B:731-735.

Zajic JE, Supplison B (1972). Emulsification and degradation of bunker C. fuel oil by microorganisms. Biotechnol. Bioeng. 14:331-343. 